\title{
BIMETALLIC GOLD/SILVER ALLOY NANOPARTICLES PREPARED IN THE PRESENCE OF TRYPTOPHAN
}

\author{
N. Vityuk ${ }^{1}$, Iu. Mukha ${ }^{1}$, G. Grodzyuk ${ }^{2,3}$, A. Eremenko ${ }^{1}$ \\ ${ }^{1}$ Chuiko Institute of Surface Chemistry of National Academy of Sciences of Ukraine, \\ 17 General Naumov Str. Kyiv, 03164, Ukraine \\ ${ }^{2}$ L.V. Pisarzhevskii Institute of the Physical Chemistry, NASU, 31 Nauki Ave., Kyiv 03028, Ukraine \\ ${ }^{3}$ NanoMedTech LLC, 68 Gorkogo str., Kyiv 03150, Ukraine.
}

The stable colloidal solutions of monometallic and bimetallic gold and silver nanoparticles (NPs) have been obtained in the presence of amino acid tryptophan. For the synthesis of bimetallic composition the metals were used in a molar ratio of Ag:Au =3:1, 1:1 and 1:3. The only one plasmon resonance band in absorption spectra was located between the bands inherent to the individual metals and it was characteristic for "alloy" type bimetallic AgAu NPs. The position of its maximum strongly depends on the Ag:Au molar ratio. The surface of all synthesized nanoparticles carries a negative charge due to the stabilizing shell consisted of amino acid. In the paper we usedUV/visible spectroscopy and dynamic light scattering method to analyze the effect of experimental procedure on the properties of obtained NPS.

\section{Introduction}

Gold and silver nanoparticles (NPs) can be applied as well or in combination with other objects for targeting, imaging and therapy[1-4]. Their bimetallic composition could act more effectively in cancer treatment due to synergetic effect. Also, the toxicity of bimetallic NPs can be greatly decreased through the use of essential amino acid as reducing and stabilizing agent [5]. Here we used tryptophan for reduction of metal ions and also for stabilization of NPs in the colloid.

The formation of gold and silver NPs in the presence of tryptophan is strongly influenced by the acidity of initial components as we showed earlier [6,7]. Based on the previous study here we used initial reagents with the best combination of $\mathrm{pH}$ for the synthesis of stable bimetallic "alloy" AgAuNPs. The aim was to analyze the influence of experimental procedure on final properties of colloids synthesized in three series using the same concentrations and metal ratios of the components.

\section{Experimental}

Colloidal solutions of mono- and bimetallic silver and gold NPs were obtained via chemical reduction of silver nitrate and tetrachlorauratic acid $\left(\mathrm{AgNO}_{3}\right.$ and $\mathrm{HAuCl}_{4}, \mathrm{Merck}$, Germany) with amino acid tryptophan (Trp, SC12-20120713, China). The components interacted in a molar ratio $\mathrm{M}: \operatorname{Trp}=1: 1$. The concentrations in the resulting solution used were $C(M)=10^{-4} \mathrm{M}$. The initial metal molar ratios in bimetallic composition were $3: 1,1: 1$ and $1: 3$. For all colloids, the initial solutions of the components were adjusted to required $\mathrm{pH}$ that was 4 for gold and 10 for silver. Amino acid was used in an anionic state that exists in alkaline medium. Initial solutions of the components of $2 \times 10^{-4} \mathrm{M}$ were mixed in equal volumes when stirred and heated continuously to boiling. The series of samples obtained when (I) metals were injected into the heated solution of Trp one by one, silver before gold, (II) metals were injected simultaneously into heated solution of Trp, (III) metals were heated and injected simultaneously into heated solution of Trp.

The $\mathrm{pH}$ measurements were performed using a $\mathrm{pH}$-meter I-160MI. As a working electrode, a glass electrode was used. Silver chloride electrode served as a reference one.

The absorption spectra of the colloidal solutions of $\mathrm{Ag}(\mathrm{Au}) \mathrm{NPs}$ were recorded in the UV-visible region with a spectrophotometer Lambda 35 (Perkin-Elmer, United States) in 1 cm quartz cells. 
The particle size distribution function and zeta potential measurement were studied by a laser correlation spectrometer Zeta Sizer Nano S (Malvern, UK) equipped with a correlator (multi-computing correlator type $7032 \mathrm{ce}$ ) by the method based on the scattering of light on any micro-objects. The information signal from the random movement of nanoparticles was analyzed by multi-channel spectrum analyzer and colorimeters. $1 \mathrm{ml}$ of studied suspension was placed in a cylindrical optical glass cell with a diameter of $10 \mathrm{~mm}$ located in the thermostatted sample holder of the laser correlation spectrometer. Registration and statistical processing of the scattered laser light at $173^{\circ}$ from the suspension (helium-neon laser LGN111 was used with a power output of $25 \mathrm{~mW}$ and wavelength of $633 \mathrm{~nm}$ ) were performed three times for 120 seconds at $25^{\circ} \mathrm{C}$. The resulting autocorrelation function was treated with standard computer programs PCS-Size mode v 1.61 .

\section{Results and discussion}

The phenomenon of localized surface plasmon resonance (LSPR) causes a bright red color of gold nanoparticles (NPs)[8]. Colloids of monometallic nanosized gold obtained in the presence of the amino acid tryptophan (Trp) were also red colored. In UV-vis spectra, absorption band maxima of Au NPs were located near $525 \mathrm{~nm}$. Meanwhile, silver NPs with intrinsic yellow coloration had LSPR band near $420 \mathrm{~nm}$. Three series of samples of bimetallic $\mathrm{AgAu}$ NPs synthesized with the same content of reagents but with some difference in experimental procedure are indicated as (I), (II) and (III) as described above.

Zeta potential measurements of all tryptophan-capped Ag, Au and AgAu NPs showed that surface of synthesized nanoparticles carried a negative charge (Table 1). It led to the stability of colloids during a year even when stored light at room temperature.

In absorption spectra, the only one band maximum is characteristic for "alloy" type NPs when $\mathrm{Ag}^{+}$and $\left[\mathrm{AuCl}_{4}\right]^{-}$ions are simultaneously reduced. It is located between the maxima inherent to the bands of individual metals and depends on the composition of the particle [9]. It is shifted from silver to gold gradually according to decreasing Ag:Au molar ratio (Table 1). The coloration of colloids also changed from yellow, then orange to red.

Table 1. Positions of absorption band maxima and zeta potentials of synthesized nanoparticles

\begin{tabular}{|c|c|c|c|c|c|c|c|}
\hline \multirow{2}{*}{$\mathrm{N}$} & \multirow{2}{*}{$\begin{array}{c}\text { Sample, } \\
\mathrm{C}=10^{-4} \mathrm{M}\end{array}$} & \multicolumn{3}{|c|}{$\lambda_{\max }, \mathrm{nm}$} & \multicolumn{3}{|c|}{ zeta potential, $\mathrm{mV}$} \\
\cline { 3 - 8 } & & $\mathrm{I}$ & $\mathrm{II}$ & $\mathrm{III}$ & $\mathrm{I}$ & $\mathrm{II}$ & $\mathrm{III}$ \\
\hline 1 & $\mathrm{Ag} \mathrm{NPs}$ & 417 & 425 & 416 & -27 & -21 & -23 \\
\hline 2 & $\mathrm{AgAu} \mathrm{(3:1)}$ & 441 & 434 & 438 & -21 & -26 & -26 \\
\hline 3 & $\mathrm{AgAu} \mathrm{(1:1)}$ & 494 & 469 & 464 & -13 & -29 & -26 \\
\hline 4 & $\mathrm{AgAu} \mathrm{(1:3)}$ & 508 & 498 & 496 & -25 & -11 & -21 \\
\hline 5 & $\mathrm{Au} \mathrm{NPs}$ & 526 & 523 & 527 & -20 & -21 & -15 \\
\hline
\end{tabular}

No significant difference was observed between $\lambda_{\max }$ positions of bimetallic AgAu NPs when initial solutions of metals injected simultaneously to the reaction mixture both previously heated (III) and not heated (II). But adding solutions of $\mathrm{HAuCl}_{4}$ after $\mathrm{AgNO}_{3}$ to the mixture (I) caused the red shift of $\lambda_{\max }$ for all three ratios compare to (II) and (III). Moreover, for (I) a long-wavelength shoulder appeared, the most prominent for the ratio $\mathrm{Ag}: \mathrm{Au}=3: 1$ (Fig. 1a). Despite the reduction by tryptophan is not immediate and can take a long time (few days with heating), the possible explanation of this phenomenon can be the formation of NPs of core-shell type because metals were added sequentially[10]. Also, the longitudinal LSRP absorption [11] of aggregated particles influenced on the interpretation of $\mathrm{UV} /$ vis spectra. 

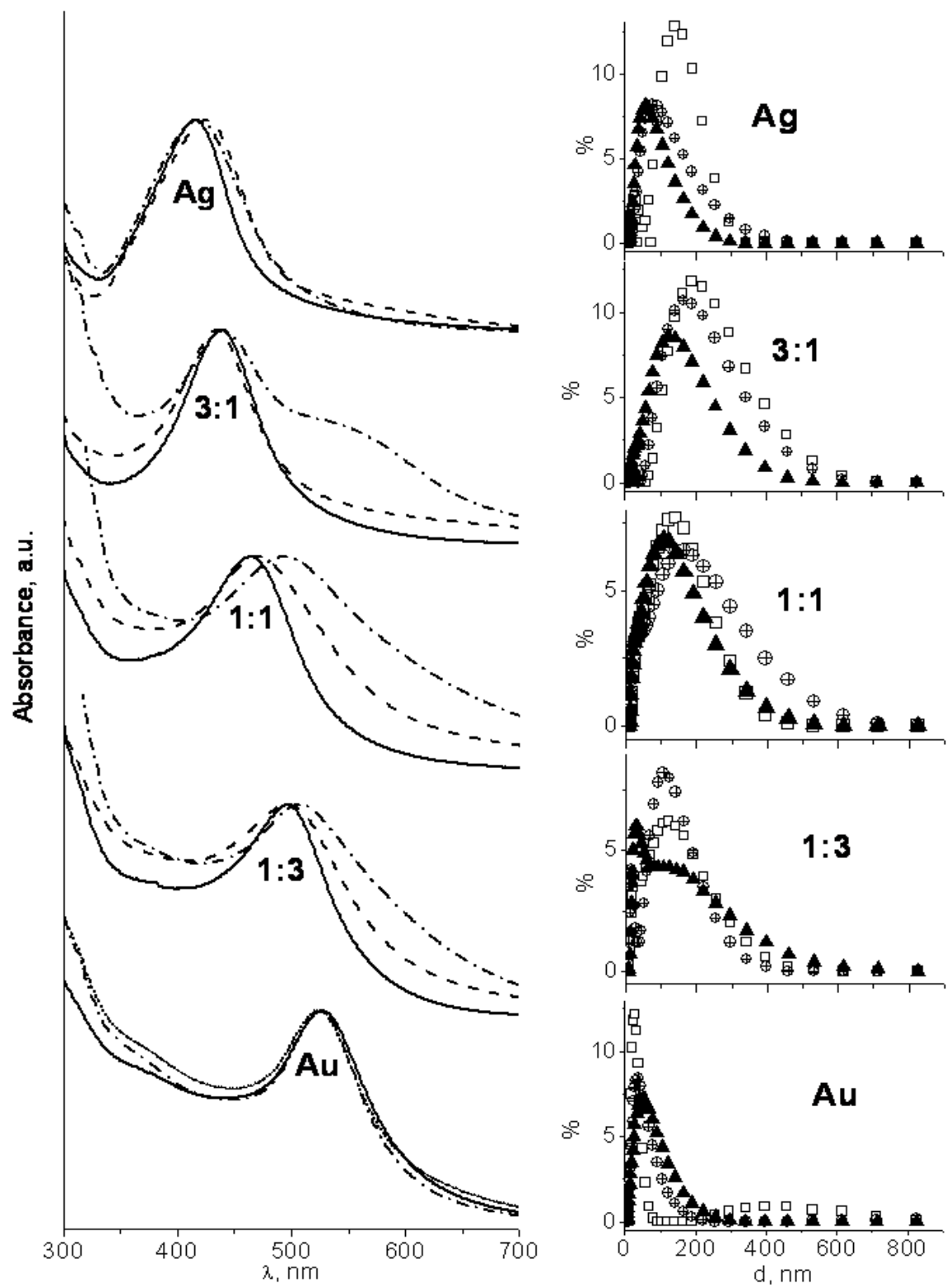

$a$

$b$

Fig. 1. Optical spectra of colloidal solutions of monometallic NPs and bimetallic composition with different metal molar ratios (a), where different series are indicated as (I) dash-dot line, (II) dash line and (III) solid line; polydispersity in colloidal solutions reflected as the particle size distribution by intensity basis (b), where different series are indicated as (I) square, (II)circle and (III) triangle.

Broad LSPR bands in the spectra of all nanoparticles with different metal ratios indicated polydispersity in colloidal solutions. We suggest that it can be the aggregation of small NPs occurring due to cross-linking of particles through tryptophan during the synthesis. The existence of small particles is confirmed by the characteristic position of LSPR band. Polydispersity in colloids was evidenced by the dynamic light scattering (DLS) data. Intensity basis suggested the formation of a wide range of structures up to several hundreds of nanometers for all bimetallic AgAu NPs (Fig. 1b).

For colloids obtained from all previously heated initial solutions (III), LSPR absorption bands were the narrowest and the most symmetrical, as well as the size distribution of particles by intensity indicated the smallest particles among other series (Table 2). One 
more finding is that according to DLS, the more content of gold in bimetallic composition, the smaller aggregates formed.

Table 2. Size distribution of bimetallic nanoparticles by DLS

\begin{tabular}{|c|c|c|c|c|c|c|c|}
\hline \multirow{2}{*}{$\mathrm{N}$} & \multirow{2}{*}{$\begin{array}{c}\text { Ag:Au } \\
\text { molar ratio }\end{array}$} & \multicolumn{2}{|c|}{$\mathrm{d}, \mathrm{nm}$ (more than 60\%) } & \multicolumn{2}{c|}{$\mathrm{d}, \mathrm{nm}$ (more than 30\%) } \\
\cline { 3 - 8 } & & $\mathrm{I}$ & $\mathrm{II}$ & $\mathrm{III}$ & $\mathrm{I}$ & $\mathrm{II}$ & $\mathrm{III}$ \\
\hline 2 & $3: 1$ & $140-300$ & $100-250$ & $70-220$ & $160-220$ & $140-190$ & $100-160$ \\
\hline 3 & $1: 1$ & $60-220$ & $50-250$ & $50-220$ & $100-190$ & $100-190$ & $80-140$ \\
\hline 4 & $1: 3$ & $40-250$ & $50-220$ & $20-120$ & $90-160$ & $90-140$ & $30-80$ \\
\hline
\end{tabular}

The properties of bimetallic NPs with different metal ratios are affected by the mechanism of reduction for two metals. Probably higher red-ox potential of gold caused faster oxidation of amino acid (reduction of metal) and thus smaller particle formation. However, donor-acceptor complex formation with amino acid plays a key role because in aqueous solution adjusted to high $\mathrm{pH}$ Trp exists in anionic form and has a nonbonding pair of electrons on the nitrogen atom of the amino group and deprotonated carboxylic group -COO-. Thus, the whole process is very complicated. Donor-acceptor complex with metal on the surface of one NP is formed simultaneously with the charge-transfer complex one with indole moiety on the surface of another NP causing the aggregation in the system.

\section{Conclusions}

Reduction of the noble metal with tryptophan leads to the formation of large aggregates of NPs in the system for both mono- and bimetallic NPs. The heating of all initial solutions, as well as simultaneous injection of metal to the reaction mixture, causes the formation of the smallest aggregates of bimetallic NPs.

\section{References}

1. J. Conde, G. Doria, P. Baptista, Noble Metal nanoparticles applications in cancer // J. Drug Deliv. - 2012. - doi: 10.1155/2012/751075.

2. Babu, A. K. Templeton, A. Munshi, R. Ramesh. Nanoparticle-Based Drug Delivery for Therapy of Lung Cancer: Progress and Challenges // J.Nanomater. - 2013. doi: $10.1155 / 2013 / 863951$.

3. W. Cai, T. Gao, H. Hong, J. Sun. Applications of gold nanoparticles in cancer nanotechnology// Nanotechnol. Sci. Appl. - 2008. - V. 1. - P. 17-32.

4. M. Babaei, M. Ganjalikhani. A systematic review of gold nanoparticles as novel cancer therapeutics // J. Nanomedicine. - 2014. - V.1(4). - P. 211-219.

5. O. Shmarakov, Iu. P. Mukha, V. V. Karavan, O. Yu. Chunikhin, M. M. Marchenko, N. P. Smirnova, A. M. Eremenko. Tryptophan-assisted synthesis reduces bimetallic gold/silver nanoparticle cytotoxicity and improves biological activity // Nanobiomedicine. - 2014. -doi: 10.5772/59684.

6. Iu. Mukha, N. Vityuk, O. Severynovska, A. Eremenko, N. Smirnova.The pH-dependent stucture and properties of $\mathrm{Au}$ and $\mathrm{Ag}$ nanoparticles produced by tryptophan reduction // Nanoscale Res. Let. - 2016. - doi: 10.1186/s11671-016-1318-8

7. Н. В. Вітюк, Ю. П. Муха, С. М. Махно, Г. М. Сременко, Н. П. Смірнова. Стабілізація наночастинок срібла у присутності триптофану // Поверхность. 2015. - Вып. 7(22). - С. 222-226

8. Louis, O. Pluchery. Gold nanoparticles for physics, chemistry and biology//Imperial College Press. 2012: 395 pp.

9. Link S., Wang Z.L., El-Sayed M.A.Alloy Formation of Gold-Silver Nanoparticles and the Dependence of the PlasmonAbsorption on Their Composition // J. Phys. Chem. B. 1999.- V. 103. - P. 3529-3533. 
10. Г. Яшан, Ю. Муха, Г. Крилова, Н. Смірнова, А. Сременко. Спектральні характеристики біметалічних кластерів $\mathrm{Ag} / \mathrm{Au}$ (ядро-оболонка та сплав), одержаних фотохімічним та хімічним шляхами // Всеукраїнська міжнародна конференція молодих вчених “Наноматеріали в хімії, біології та медицині”. Київ, Україна, 15-17 травня, 2007. - С. 137-138.

11. Stephan Link, Mostafa A. El-Sayed.Spectral Properties and Relaxation Dynamics of Surface Plasmon Electronic Oscillations in Gold and Silver Nanodots and Nanorods// J. Phys. Chem. B. - 1999. - V. 103. - P. 8410-8426

\title{
БІМЕТАЛЬНІ НАНОЧАСТИНКИ СПЛАВУ ЗОЛОТО/СРІБЛО СИНТЕЗОВАНІ У ПРИСУТНОСТІ ТРИПТОФАНУ
}

\author{
Н. Вітюк ${ }^{1}$ Ю. Муха $^{1}$, Г. Гродзюк ${ }^{2,3}$, Г. Єременко ${ }^{1}$ \\ ${ }^{1}$ Інститут хімії поверхні ім. О.О. Чуйка Національної академії наук Украӥни, \\ вул. Генерала Наумова, 17, Київ, 03164, Украӥна \\ ${ }^{2}$ Інститут фізичної хімії ім. Л.В. Писаржевського НАН України, просп. Науки 31, м. \\ Киї, Україна, 03028 \\ ${ }^{3}$ ТОВ НаноМедТех вул. Горького 68, м. Київ, Украӥна, 03150
}

Стабільні колоїдні розчини наночастинок (НЧ) срібла та золота та їх біметалічні композити зі співвідношенням металів $\mathrm{Ag}: \mathrm{Au}=3: 1,1: 1,1: 3$ синтезовані у присутності амінокислоти триптофану. В спектрах поглинання присутня лише одна смуга поглинання плазмонного резонансу НЧ, характерна для біметальних наночастинок сплаву $A g A u$, розташована між смугами індивідуальних металів. Положення максимуму поглинання дуже залежить від мольного співвідношення Ag:Au. Поверхня всіх синтезованих наночастинок має негативний заряд за рахунок стабілізуючою оболонки амінокислоти. Проаналізовано вплив експериментальних методик на властивості одержаних НЧ за допомогою УФ/видимої спектроскопії $i$ методу динамічного світлорозсіювання.

\section{БИМЕТАЛЛИЧЕСКИЕ НАНОЧАСТИЦЫ ЗОЛОТО/СЕРЕБРО ТИПА СПЛАВ, СИНТЕЗИРОВАННЫЕ В ПРИСУТСТВИИ ТРИПТОФАНА}

\author{
Н. Витюк ${ }^{1}$ Ю. Муха ${ }^{1}$ Г. Гродзюк ${ }^{2,3}$, А. Еременко ${ }^{1}$
}

${ }^{1}$ Институт химии поверхности им. А.А. Чуйко Национальной академии наук Украинь,, ул. Генерала Наумова, 17, Киев, 03164, Украина

${ }^{2}$ Институт физической химииим. Л.В. Писаржевского НАН Украины, просп. Науки 31, 2. Киев, Украина, 03028

${ }^{3}$ ООО НаноМедТех, ул. Горького 68, г. Киев, Украина, 03150

Стабильные коллоидные растворы наночастии (НЧ) серебра и золота, а так же их биметаллические композить с соотношением металлов $\mathrm{Ag}: \mathrm{Au}=3: 1,1: 1,1: 3$ синтезированы в присутствии аминокислоты триптофана. В спектрах поглощения присутствует только одна полоса плазмонного резонанса НЧ, характерная для биметаллических наночастии сплава $\mathrm{AgAu,} \mathrm{находящаяся} \mathrm{между} \mathrm{полосами} \mathrm{НЧ}$ отдельных металлов. Положение ее максимума сильно зависит от мольного соотношения Ag:Au. Поверхность всех синтезированных наночастии имеет отрицательный заряд за счёт стабилизирующей оболочки аминокислоты. Проанализировано влияние экспериментальных методик на свойства полученных НЧ с помощью УФ/видимой спестроскопии и метода динамического светорассеивания. 